\title{
Kernel quality and morphological traits of scented rice (cv. Super Basmati) in relation to irrigation and zinc application
}

\author{
Zuhair Hasnain* and Hakoomat Ali \\ Department of Agronomy and Soil Science, BahauddinZakariya University, Multan-60800, Pakistan.
}

.Accepted 14 August, 2013

\begin{abstract}
Two year field study was conducted at Adaptive Research Farms Sheikhupura and Sargodha with the objective to investigate the impact of irrigation water and zinc application on kernel quality and morphological traits of scented rice, and genotype Super Basmati was selected for this study. Results indicated that increasing applications of irrigation and zinc has positive influence on kernel quality and morphological characters of super basmati, and from two sites data of two growing seasons it was concluded that 14 irrigations and application of zinc at $14 \mathrm{~kg} \mathrm{ha}^{-1}$ seems best to obtain optimum response in fine rice. Correlation coefficient between grain yield and morphological characteristics of aromatic rice was also studied and the data showed that grain yield was significantly and positively correlated with quality attributes at both experimental sites.
\end{abstract}

Key words: Physiochemical properties, economic yield, water treatments, fertilization, Oryza sativa L.

\section{INTRODUCTION}

Rice (Oryza sativa L.) is one of the most important cereal crops and is staple food for more than $50 \%$ of the world's population (Fageria et al., 2008). In Pakistan it holds second position in consumption after wheat and is grown on an area of 2963 thousands hectares, with an annual production of 6952 thousand tons, having an average yield of $2346 \mathrm{~kg} \mathrm{ha}^{-1}$ (GOP, 2009). The yield potential of Basmati varieties ranges from 4.5 to 6 tha $^{-1}$ while the actual yield of Basmati varieties obtained by the farmers is 2.0 to $2.8 \mathrm{t} \mathrm{ha}^{-1}$ (Ahmad et al., 2005; Shivay et al., 2010). Water scarcity is increasing in the world (Xie et al., 2008). Adequate water supply is one of the most important factors in enhancing crop production. Sharma et al. (2008) found significant effect of pre-sowing irrigation on both the grain and straw yield and on the nutrient concentration of rice crop. Crusciol et al. (2003) studied effects of irrigation levels on the quality and grain nutrient content of upland rice and found synergistic effects. Zinc (Zn) deficiency in rice has been reported from all over the world (Mirzavand, 2007), and is a barrier in achieving yield targets in crops particularly in rice growing areas (Shivay et al., 2008, 2010). Its deficiency causes a considerable reduction (25 to $50 \%$ ) in paddy yield, so its application at proper time and quantity has a vital importance for maximizing production of rice (Ahmad et al., 2005; Hussain et al., 2005). Review of literature showed that data on the zinc and water application of Basmati rice is lacking in Pakistan, and limited information is available over their impact on quality and morphological characters of transplanted fine rice so the present study was chalked out to optimize traits under consideration in relation to water and zinc use. 
Table 1. Physical and chemical analysis of experimental soils.

\begin{tabular}{lccc}
\hline Determination & Unit & Sheikhupura & Sargodha \\
\hline Physical analysis & & & \\
Sand & $\%$ & 14 & 23 \\
Silt & $\%$ & 70 & 60 \\
Clay & $\%$ & 16 & 17 \\
Textural class & $\%$ & Loam & Silty loam \\
Chemical analysis & & & \\
pH & & 8.40 & 7.60 \\
Total soluble salt & $\%$ & 10.1 & 15.02 \\
Organic matter & $\%$ & 0.80 & 0.96 \\
Total nitrogen & $\%$ & 0.07 & 0.06 \\
Available phosphorus & $\mathrm{ppm}$ & 10.4 & 16.80 \\
Available potassium & $\mathrm{ppm}$ & 204 & 235 \\
\hline
\end{tabular}

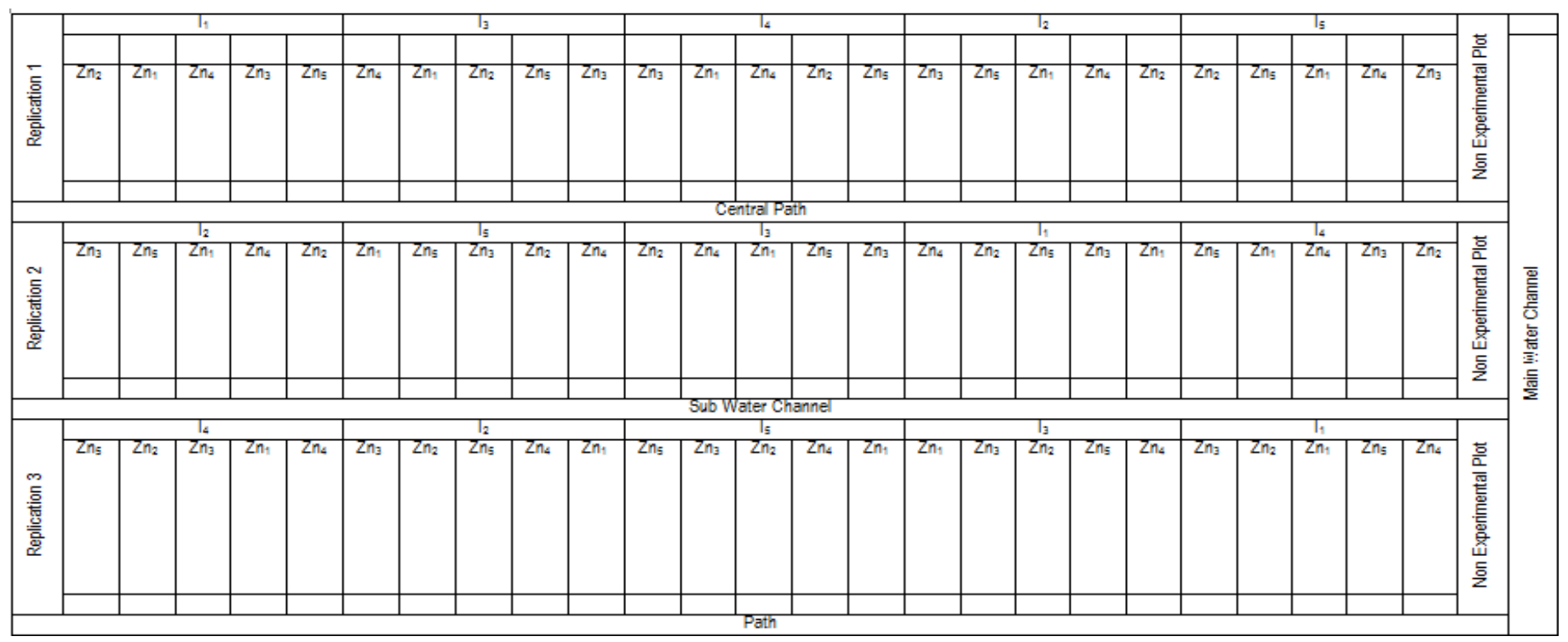

Figure 1. Layout plan of experiment. Treatments: A. Irrigation levels main plot: $I_{1}: 6 ; I_{2}: 8 ; I_{3}: 10 ; I_{4}: 12 ; I_{5}: 14$. B. Zinc rates sub plot: Zn $n_{1}: 0$ $\mathrm{kg} \mathrm{ha}^{-1} ; \mathrm{Zn}_{2}: 8 \mathrm{~kg} \mathrm{ha}^{-1} ; \mathrm{Zn}_{3}: 10 \mathrm{~kg} \mathrm{ha}^{-1} ; \mathrm{Zn}_{4}: 12 \mathrm{~kg} \mathrm{ha}^{-1} ; \mathrm{Zn}_{5}: 14 \mathrm{~kg} \mathrm{ha}^{-1}$; Replication: 3; Plot size: $1.8 \mathrm{~m} \times 12 \mathrm{~m}$; Plant to plant distance: 22.5 $\mathrm{cm}$; Row to row distance: $22.5 \mathrm{~cm}$; Fertilizer N:P:K: 140:80:60 kg ha'

\section{MATERIALS AND METHODS}

\section{Location}

Field studies were conducted at Adaptive Research Farm Sheikhupura $\left(31.6^{\circ} \mathrm{N}, 74.6^{\circ} \mathrm{E}, 217 \mathrm{~m}\right)$ and Sargodha $\left(32.04^{\circ} \mathrm{N}\right.$, $72.67^{\circ} \mathrm{E}, 188 \mathrm{~m}$ ) over a period of two growing seasons (2009, 2010).

\section{Soil analysis}

Composite soil sample to a depth of $30 \mathrm{~cm}$ was obtained from the experimental area with soil auger prior to sowing of crop. The sample was analyzed for its physio-chemical properties. Percentage of sand, silt and clay was determined by Bouyoucos hydrometer method using $1 \%$ sodium hexametaphosphate as a dispersing agent. Textural class was determined using the international textural triangle (Moodie et al., 1959). Soil analysis showed that at Sargodha soil was silty loam in texture whereas in case of Sheikhupura the soil texture was loam (Table 1). The method of Homer and Pratt (1961) was used to determine various chemical properties of the experimental soil that showed that both sites had $\mathrm{pH}$ near 8.00. Moreover, soils of both the sites were rated as deficient in organic matter and elements like $\mathrm{N}, \mathrm{P}, \mathrm{K}$, etc.

\section{Design and treatments}

Experiment was laid out in randomized complete block design with split arrangement replicated thrice. Treatments were five irrigation levels $\left(I_{1}=6, I_{2}=8, I_{3}=10, I_{4}=12, I_{5}=14\right)$ in main plots and five $\mathrm{Zn}$ application rates $\left(Z \mathrm{n}_{1}=0 \mathrm{~kg}\right.$ ha ${ }^{-1}, Z \mathrm{n}_{2}=8 \mathrm{~kg} \mathrm{ha}{ }^{-1}, Z \mathrm{n}_{3}=10 \mathrm{~kg} \mathrm{ha}^{-1}$, $\mathrm{Zn}_{4}=12 \mathrm{~kg} \mathrm{ha}^{-1}, \mathrm{Zn}_{5}=14 \mathrm{~kg} \mathrm{ha}^{-1}$ ) in sub plots. There were total 25 plots with a net plot size of $1.8 \mathrm{~m} \times 12 \mathrm{~m}$ long with row to row and plant to plant spacing of $22.5 \mathrm{~cm}$ (Figure 1). 
Table 2. Crop husbandry operations for the experiments at Sheikhpura and Sargodha.

\begin{tabular}{lcc}
\hline Operations & Sheikhupura & Sargodha \\
\hline Nursery sowing date & $05.06 .09 / 10$ & $05.06 .09 / 10$ \\
Cultivation (puddling) & $02.07 .09 / 10$ & $02.07 .09 / 10$ \\
Transplanting dates & $05.07 .09 / 10$ & $06.07 .09 / 10$ \\
Fertilizer [P (SSP) at $80 \mathrm{~kg} \mathrm{ha}^{-1}$ ] & $05.07 .09 / 10$ & $06.07 .09 / 10$ \\
$\mathrm{~K}(\mathrm{SOP})$ at $60 \mathrm{~kg} \mathrm{ha}^{-1}$ & $05.07 .09 / 10$ & $06.07 .09 / 10$ \\
$\mathrm{~N}\left(\right.$ Urea) $140 \mathrm{~kg} \mathrm{ha}^{-1} \mathrm{~N}_{1}$ & $05.07 .09 / 10$ & $06.07 .09 / 10$ \\
$\mathrm{~N}_{2}$ & $31.07 .09 / 10$ & $01.08 .09 / 10$ \\
$\mathrm{Crop}$ establishment & $16.07 .09 / 10$ & $16.07 .09 / 10$ \\
Hand weeding & $22.07 .09 / 10$ & $23.07 .09 / 10$ \\
Irrigation & & \\
Date of sampling & & \\
33 days after transplanting (DAT) & $08.08 .09 / 10$ & $08.08 .09 / 10$ \\
47 days after transplanting (DAT) & $22.08 .09 / 10$ & $23.08 .09 / 10$ \\
61 days after transplanting (DAT) & $05.09 .09 / 10$ & $06.09 .09 / 10$ \\
75 days after transplanting (DAT) & $19.10 .09 / 10$ & $20.10 .09 / 10$ \\
89 days after transplanting (DAT) & $02.10 .09 / 10$ & $03.10 .09 / 10$ \\
103 days after transplanting (DAT) & $16.11 .09 / 10$ & $17.11 .09 / 10$ \\
Final harvest & $30.11 .09 / 10$ & $01.12 .09 / 10$ \\
\hline
\end{tabular}

*A flooded condition was maintained continuously throughout the active growth period of the rice crop.

\section{Crop husbandry}

Crop was transplanted manually on respective dates on puddled field (Table 2). Recommended doses of phosphorus and potassium, that is, 80 and $60 \mathrm{~kg} \mathrm{ha}^{-1}$ in the form of single super phosphate (SSP) and potassium sulphate were applied to all plots at the time of puddling before transplanting during both seasons. Nitrogen was applied in the form of urea at the rate of $140 \mathrm{~kg} \mathrm{ha}^{-1}$. Half of nitrogen fertilizer was applied to all plots at the time of puddling before transplanting and remaining half of nitrogen at 30 days after transplanting (DAT). Zinc was applied in the form of zinc sulphate and half of its dose was applied to all plots at the time of puddling before transplanting and remaining was applied at active tillering (dose as per treatments). Buffer plots were maintained to avoid seepage/border effect of irrigation among various treatments. Agronomic practices such as weeding, irrigation and plant protection measures etc. were kept normal and uniform for all the treatments.

\section{Parameters of quality and morphological characters studied}

\section{Sterility, opaque, abortive and normal kernels}

Sterile spikelets, opaque, abortive and normal kernels were counted from ten panicles from the primary tillers randomly selected from each treatment. The whole panicles were carefully sketched to differentiate between sterile spikelets, abortive, opaque and normal kernels (Nagato and Chaudhry, 1969). A common electric lamp with a flexible stand was used as a source of light. A panicle was positioned in front of the lamp so that light may pass through it in order to differentiate different stages of kernel development. Number of sterile spikelets, abortive, opaque and normal kernels from each sketch of all the treatments were counted, averaged and expressed in percent.

\section{Kernel protein content}

Protein contents of rice seed were estimated by micro Kjeldalh digestion to determine nitrogen content, which is then converted to protein by multiplying with the factor 5.9 (Jacobs, 1958).

\section{Kernel amylose content}

Milled and grounded rice seed was used for the determination of amylose content according to the method prescribed by Juliano (1971). The intensity of blue color was read in a spectronic photometer 20 (Baush and Lomb) at $620 \mathrm{~nm}$.

\section{Dimensions of kernel}

Kernel dimensions (length and width) were taken on 100 normal kernels from each treatment with the help of a dial caliper.

\section{Kernel water absorption ratio}

The water absorption ratio was determined by the formula reported by Juliano et al. (1965): Water absorption ratio (WAR) $=$ Weight of cooked rice/weight of raw rice

\section{Statistical analysis}

Data collected was analyzed statistically by employing the Fisher's analysis of variance technique on personal computer. The effect of I and $\mathrm{Zn}$ rates was analyzed using polynomial contrast within the analysis of variance structure. The significance of treatment means was tested using least significance difference (LSD) test at $5 \%$ probability level (Steel et al., 1997). 
Table 3. Year, irrigation and zinc impact on quality and morphological parameters of super basmati at Sheikhupura (SH) and Sargodha (SG).

\begin{tabular}{|c|c|c|c|c|c|c|c|c|c|c|c|c|c|c|c|c|c|c|}
\hline \multirow{2}{*}{$\begin{array}{l}\text { Treatment } \\
A=\text { Year }\end{array}$} & \multicolumn{3}{|c|}{ Spikelet sterility (\%) } & \multicolumn{3}{|c|}{ Abortive kernels (\%) } & \multicolumn{3}{|c|}{ Opaque kernels (\%) } & \multicolumn{3}{|c|}{ Normal kernels (\%) } & \multicolumn{3}{|c|}{ Water absorption ratio } & \multicolumn{3}{|c|}{ Grain yield $\left(\mathrm{gm}^{2}\right)$} \\
\hline & $\mathrm{SH}$ & SG & Mean & $\mathrm{SH}$ & SG & Mean & $\mathrm{SH}$ & SG & Mean & SH & SG & Mean & $\mathrm{SH}$ & SG & Mean & $\mathrm{SH}$ & SG & Mean \\
\hline 2009 & 6.82 & 6.55 & 6.69 & 7.69 & $7.58^{a}$ & 7.64 & 7.05 & 6.87 & 6.96 & 65.31 & 66.39 & 65.85 & 3.36 & $3.09^{a}$ & 3.23 & 401 & $370^{b}$ & 386 \\
\hline 2010 & 6.81 & 6.64 & 6.73 & 7.71 & $6.97^{b}$ & 7.37 & 6.90 & 6.83 & 6.87 & 66.10 & 65.76 & 65.93 & 3.11 & $2.83^{b}$ & 2.97 & 400 & $381^{a}$ & 391 \\
\hline LSD 5\% & NS & NS & & NS & 0.38 & & NS & NS & & NS & NS & & NS & 0.21 & & NS & 0.12 & \\
\hline $\mathrm{Sx}^{-}$ & 0.239 & 0.051 & & 0.266 & 0.088 & & 0.266 & 0.065 & & 2.393 & 0.719 & & 0.085 & 0.050 & & 0.129 & 0.027 & \\
\hline \multicolumn{19}{|l|}{$B=$ Irrigation levels } \\
\hline$\left.\right|_{1}: 6$ & $5.98^{c}$ & $6.40^{c}$ & 6.19 & $6.90^{d}$ & $6.98^{c}$ & 6.94 & $6.25^{\mathrm{e}}$ & $6.67^{c}$ & 6.46 & $61.91 \mathrm{e}$ & $61.94^{c}$ & 61.93 & $2.88^{e}$ & $2.81^{b}$ & 2.85 & $275^{e}$ & $265^{d}$ & 270 \\
\hline$\left.\right|_{2}: 8$ & $6.12^{c}$ & $6.53^{c}$ & 6.33 & $6.94^{d}$ & $7.00^{c}$ & 6.97 & $6.41^{d}$ & $6.62^{c}$ & 6.52 & $64.83^{d}$ & $65.87^{b}$ & 65.35 & $2.99 \mathrm{~d}$ & ‘82.94a & 2.97 & $318^{d}$ & $337^{c}$ & 328 \\
\hline$\left.\right|_{3}: 10$ & $6.48^{b}$ & $6.50^{c}$ & 6.49 & $7.49 c$ & $7.13^{c}$ & 7.31 & $6.80^{c}$ & $6.71^{\mathrm{c}}$ & 6.76 & $66.37^{c}$ & $66.46^{b}$ & 66.42 & $3.53^{a}$ & $3.00^{a}$ & 3.27 & $386^{c}$ & $388^{b}$ & 387 \\
\hline $\mid 4: 12$ & $7.81^{\mathrm{a}}$ & $6.69 \mathrm{~b}$ & 7.25 & $8.79^{a}$ & $7.54^{\mathrm{b}}$ & 8.17 & $7.88^{a}$ & $6.99 \mathrm{~b}$ & 7.44 & $67.97^{a}$ & $68.42^{\mathrm{a}}$ & 68.20 & $3.33^{c}$ & $3.04^{a}$ & 3.19 & $537^{a}$ & $490^{\mathrm{a}}$ & 514 \\
\hline $\mid 5: 14$ & 7.68 & $6.86^{\mathrm{a}}$ & 7.27 & $8.37^{b}$ & $7.74^{a}$ & 8.06 & $7.52^{b}$ & $7.26^{\mathrm{a}}$ & 7.39 & $67.46^{b}$ & $67.68^{a}$ & 67.57 & $3.43^{b}$ & $3.00^{\mathrm{a}}$ & 3.22 & $488^{b}$ & $398^{b}$ & 443 \\
\hline LSD 5\% & 0.19 & 0.15 & & 0.17 & 0.18 & & 0.11 & 0.25 & & 0.24 & 0.98 & & 0.09 & 0.12 & & 0.17 & 0.20 & \\
\hline$S x^{-}$ & 0.091 & 0.073 & & 0.079 & 0.083 & & 0.050 & 0.118 & & 0.113 & 0.461 & & 0.044 & 0.055 & & 0.081 & 0.094 & \\
\hline \multicolumn{19}{|c|}{ C=Zinc application rate(kg/ha) } \\
\hline$Z_{1}: 0$ & $6.61^{\mathrm{c}}$ & $6.71^{\mathrm{a}}$ & 6.66 & $7.44^{\mathrm{d}}$ & $7.21^{b}$ & 7.33 & $6.43^{e}$ & $6.98^{a}$ & 6.71 & $62.76^{\mathrm{e}}$ & $60.87^{e}$ & 61.82 & $2.98^{\mathrm{e}}$ & $2.68^{\mathrm{e}}$ & 2.83 & $364^{e}$ & $322^{d}$ & 343 \\
\hline$Z n_{2}: 8$ & $6.72^{b}$ & $6.61^{\mathrm{ab}}$ & 6.67 & $7.58^{\mathrm{c}}$ & $7.22^{\mathrm{ab}}$ & 7.40 & $6.81^{\mathrm{d}}$ & $6.93^{\mathrm{ab}}$ & 6.87 & $64.79 d$ & $64.77^{d}$ & 64.78 & $3.14^{d}$ & $2.84^{\mathrm{d}}$ & 2.99 & $371^{d}$ & $357^{c}$ & 364 \\
\hline $\mathrm{Zn}_{3}: 10$ & $6.88^{a}$ & $6.56^{b}$ & 6.72 & $7.78^{b}$ & $7.30^{\mathrm{ab}}$ & 7.54 & $7.11^{c}$ & $6.85^{b c}$ & 6.98 & $65.85^{c}$ & $66.43^{c}$ & 66.14 & $3.24 c$ & $3.01^{c}$ & 3.13 & $403^{c}$ & $386^{b}$ & 395 \\
\hline$Z_{4}: 12$ & $6.91^{\mathrm{a}}$ & $6.58^{b}$ & 6.75 & $7.82^{\mathrm{ab}}$ & $7.33^{a}$ & 7.58 & $7.20^{\mathrm{b}}$ & $6.78^{\mathrm{cd}}$ & 6.98 & $66.96^{b}$ & $68.30^{b}$ & 67.63 & $3.33^{b}$ & $3.09^{b}$ & 3.21 & $423^{b}$ & $403^{a}$ & 413 \\
\hline$Z_{5}: 14$ & $6.97^{a}$ & $6.51^{b}$ & 6.75 & $7.88^{a}$ & $7.31^{\mathrm{ab}}$ & 7.60 & $7.30^{\mathrm{a}}$ & $6.70^{d}$ & 6.99 & $68.18^{a}$ & $70.00^{a}$ & 69.09 & $3.47^{a}$ & $3.17^{a}$ & 3.32 & $442^{\mathrm{a}}$ & $411^{a}$ & 427 \\
\hline LSD 5\% & 0.11 & 0.10 & & 0.08 & 0.10 & & 0.09 & 0.12 & & 0.35 & 0.28 & & 0.07 & 0.06 & & 0.05 & 0.10 & \\
\hline$S x^{-}$ & 0.053 & 0.049 & & 0.038 & 0.052 & & 0.044 & 0.062 & & 0.177 & 0.558 & & 0.038 & 0.031 & & 0.028 & 0.050 & \\
\hline Interaction (BXC) & $* *$ & $* *$ & & $* *$ & $* *$ & & $* *$ & $* *$ & & $* *$ & $* *$ & & $* *$ & $* *$ & & $\star *$ & $* *$ & \\
\hline
\end{tabular}

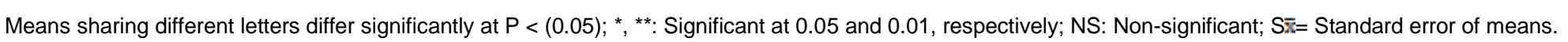

\section{RESULTS}

\section{Spikelet sterility}

There were non-significant differences regarding spikelet sterility between years at Sheikhupura and Sargodha sites. Increasing rates of irrigation application significantly and linearly increased spikelet sterility. Zinc application rate also followed a similar trend regarding spikelet sterility to that of irrigation application rate at Sheikhupura site, but differentially affected it at Sargodha (Table 3).

\section{Abortive kernels}

Table 3 showed year effect on abortive kernels was non-significant at Sheikhupura but significant at Sargodha. There were significant differences in the percentage of abortive kernels at both sites among different irrigation application rates. The abortive kernels increased with increasing irrigation application rate upto $\mathrm{I}_{4}$ (12 irrigations) treatment at Sheikhupura; thereafter it decreased significantly at $I_{5}$ (14 irrigations) application rate. Whereas at Sargodha, abortive kernels linearly increased with increasing irrigations level. Data 
also showed that increasing rate of $\mathrm{Zn}$ application significantly increased percentage of abortive kernels at both sites.

\section{Opaque kernels}

The year effect on percentage of opaque kernels was found to be non-significant at both sites. Data showed that $\mathrm{I}_{4}$ significantly increased the percentage of opaque kernels compared to other rates of irrigation application at Sheikhupura. At Sargodha $I_{5}$ increased the percentage of opaque kernels. Zn application rates showed differential but significant effect on percentage of opaque kernels at both sites (Table 3).

\section{Normal kernels}

The percentage of normal kernels was non-significant between the two cropping years. There were significant effects of irrigation application rates on the percentage of normal kernels, it increased upto $I_{4}$ (12 irrigations) and $I_{5}$ (14 irrigations) at Sheikhupura and Sargodha sites, respectively. Differences in normal kernels between $I_{4}$ and $I_{5}$ treatments at Sargodha were, however, nonsignificant. At both sites, increasing rates of $\mathrm{Zn}$ application also significantly and linearly affected the percentage of normal kernels (Table 3 ).

\section{Water absorption ratio}

Table 3 showed that year effect on water absorption ratio was significant at Sargodha but not at Sheikhupura. The increasing rate of irrigation levels significantly increased water absorption ratio up to $I_{3}$ (10 irrigations) at Sheikhupura; thereafter it significantly decreased at $\mathrm{I}_{4}$ or $I_{5}$ irrigation treatments. Whereas, at Sargodha site increasing level of irrigation increased water absorption ratio but the difference were non-significant. Data also showed that increasing rate of $\mathrm{Zn}$ application significantly and linearly increased water absorption ratio compared to control.

\section{Kernel length}

Table 4 showed that year effect on kernel length was only significant at Sargodha where kernel length was $9.0 \%$ higher in 2009 than 2010. Increasing rate of irrigation levels significantly increased kernel length at both sites, and this response was quadratic and linear at Sheikhupura and Sargodha, respectively. At both sites, increasing rates of $\mathrm{Zn}$ application significantly increased the kernel length and this response was linear in nature.

\section{Kernel width}

The year effect on kernel width was significant at Sheikhupura (Table 4). Increasing rate of irrigation levels significantly increased kernel width and this response was quadratic and linear in nature at Sheikhupura and Sargodha sites, respectively. The increasing rate of $\mathrm{Zn}$ application significantly and linearly affected kernel width compared to control at both sites.

\section{Kernel protein contents}

Table 4 showed that kernel protein contents were nonsignificant in two cropping seasons. Increasing rates of irrigation levels significantly increased kernel protein contents compared to control at both sites. Differences between $I_{3}, I_{4}$ and $I_{5}$ treatments were, however, statistically at par at both locations. At both sites, increasing rate of $\mathrm{Zn}$ application significantly and linearly enhanced kernel protein contents up to $\mathrm{Zn}_{5}\left(14 \mathrm{~kg} \mathrm{ha}^{-1}\right)$ treatments; differences between $Z n_{3}$ and $Z n_{4}$ treatments were, however, statistically at par.

\section{Kernel amylose contents}

Year effect on kernel amylose contents was found to be non-significant at both sites. Increasing rate of irrigation levels significantly enhanced kernel amylose contents upto $I_{3}$ treatment at both sites; thereafter it significantly decreased at $I_{5}$ treatment at Sargodha site. At Sheikhupura, differences between $I_{3}, I_{4}$ and $I_{5}$ treatments were, however, statistically at par regarding kernel amylose contents. Table 4 also showed significant differences in kernel amylose contents among different rates of $\mathrm{Zn}$ application. At both sites, kernel amylose contents were significantly and linearly increased with increasing $\mathrm{Zn}$ application rates.

\section{Relationship between grain yield and morphological characters}

Data in Table 5 showed that grain yield was significantly and positively correlated with spikelet sterility, abortive, opaque and normal kernels at Sheikhupura site. The kernel length was not correlated with grain yield. Both grain yield and protein and amylose contents were also positively correlated at Sheikhupura site. At Sargodha site, non-significant correlation was observed between grain yield and spikelet sterility, opaque kernels, and amylose contents. Whereas normal kernels, kernel length and kernel width were positively and significantly correlated with grain yield. Both water absorption ratio and protein contents were also positively correlated with the grain yield. The pooled data showed positive and 
Table 4. Year, irrigation and zinc impact on quality and morphological parameters of super basmati at Sheikhupura (SH) and Sargodha (SG).

\begin{tabular}{|c|c|c|c|c|c|c|c|c|c|c|c|c|c|c|c|}
\hline \multirow{2}{*}{$\begin{array}{l}\text { Treatment } \\
\mathrm{A}=\text { Year }\end{array}$} & \multicolumn{3}{|c|}{ Kernel length (mm) } & \multicolumn{3}{|c|}{ Kernel width (mm) } & \multicolumn{3}{|c|}{ Kernel protein content (\%) } & \multicolumn{3}{|c|}{ Kernel amylose content (\%) } & \multicolumn{3}{|c|}{ Grain yield $\left(\mathrm{gm}^{2}\right)$} \\
\hline & SH & SG & Mean & SH & SG & Mean & SH & SG & Mean & $\mathrm{SH}$ & SG & Mean & SH & SG & Mean \\
\hline 2009 & 7.50 & $7.22^{a}$ & 7.36 & $2.52^{a}$ & 1.77 & 2.15 & 8.62 & 8.48 & 8.55 & 22.54 & 22.44 & 22.49 & 401 & $370^{b}$ & 386 \\
\hline 2010 & 6.89 & $6.62^{b}$ & 6.76 & $1.91^{\mathrm{b}}$ & 1.73 & 1.82 & 8.34 & 8.31 & 8.33 & 22.09 & 22.31 & 22.20 & 400 & $381^{a}$ & 391 \\
\hline LSD 5\% & NS & 0.47 & & 0.17 & NS & & NS & NS & & NS & NS & & NS & 0.12 & \\
\hline$S x^{-}$ & 0.277 & 0.109 & & 0.040 & 0.019 & & 0.306 & 0.151 & & 0.711 & 0.161 & & 0.129 & 0.027 & \\
\hline \multicolumn{16}{|c|}{$\mathrm{B}=$ Irrigation levels } \\
\hline $\mathrm{I}_{1}: 6$ & $6.43^{\mathrm{e}}$ & $6.33^{d}$ & 6.38 & $1.67^{d}$ & $1.62^{\mathrm{C}}$ & 1.65 & $8.02^{c}$ & $8.06^{b}$ & 8.04 & $21.73^{b}$ & $22.84^{\mathrm{C}}$ & 21.79 & $275^{\mathrm{e}}$ & $265^{d}$ & 270 \\
\hline $\mathrm{I}_{2}: 8$ & $6.65^{d}$ & $6.58^{c}$ & 6.62 & $1.70^{\mathrm{d}}$ & $1.66^{b}$ & 1.68 & $8.23^{b}$ & $8.24^{b}$ & 8.24 & $21.95^{\mathrm{b}}$ & $22.48^{\mathrm{b}}$ & 22.22 & $318^{d}$ & $337^{c}$ & 328 \\
\hline $\mathrm{I}_{3}: 10$ & $7.07^{c}$ & $6.90^{\mathrm{b}}$ & 6.99 & $2.13^{c}$ & $1.67^{b}$ & 1.90 & $8.75^{\mathrm{a}}$ & $8.54^{\mathrm{a}}$ & 8.65 & $22.50^{\mathrm{a}}$ & $22.75^{\mathrm{a}}$ & 22.73 & $386^{c}$ & $388^{b}$ & 387 \\
\hline $\mathrm{I}_{4}: 12$ & $8.15^{\mathrm{a}}$ & $7.32^{\mathrm{a}}$ & 7.74 & $3.03^{a}$ & $1.89^{\mathrm{a}}$ & 2.46 & $8.65^{a}$ & $8.64^{a}$ & 8.65 & $22.93^{\mathrm{a}}$ & $22.49^{b}$ & 22.71 & $537^{a}$ & $490^{\mathrm{a}}$ & 514 \\
\hline$I_{5}: 14$ & $7.68^{b}$ & $7.43^{\mathrm{a}}$ & 7.56 & $2.56^{\mathrm{b}}$ & $1.91^{\mathrm{a}}$ & 2.24 & $8.73^{\mathrm{a}}$ & $8.49^{\mathrm{a}}$ & 8.61 & $22.48^{\mathrm{a}}$ & $22.30^{\mathrm{b}}$ & 22.39 & $488^{b}$ & $398^{b}$ & 443 \\
\hline LSD 5\% & 0.1 & 0.17 & & 0.09 & 0.03 & & 0.18 & 0.23 & & 0.47 & 0.21 & & 0.17 & 0.20 & \\
\hline$S x^{-}$ & 0.045 & 0.08 & & 0.043 & 0.015 & & 0.084 & 0.107 & & 0.222 & 0.099 & & 0.081 & 0.094 & \\
\hline \multicolumn{16}{|c|}{ C=Zinc application rate(kg/ha) } \\
\hline $\mathrm{Zn}_{1}: 0$ & $6.52^{\mathrm{e}}$ & $6.47^{\mathrm{e}}$ & 6.50 & $2.00^{\mathrm{C}}$ & $1.66^{d}$ & 1.88 & $8.08^{d}$ & $7.09^{d}$ & 7.59 & $21.70^{d}$ & $21.83^{d}$ & 21.77 & $364^{\mathrm{e}}$ & $322^{d}$ & 343 \\
\hline $\mathrm{Zn}_{2}: 8$ & $7.04^{d}$ & $6.78^{d}$ & 6.91 & $2.07^{c}$ & $1.71^{\mathrm{c}}$ & 1.89 & $8.30^{c}$ & $8.33^{c}$ & 8.32 & $22.10^{C}$ & $22.35^{\mathrm{C}}$ & 22.23 & $371^{d}$ & $357^{c}$ & 364 \\
\hline $\mathrm{Zn}_{3}: 10$ & $7.35^{c}$ & $6.97^{c}$ & 7.16 & $2.26^{b}$ & $1.76^{\mathrm{b}}$ & 2.01 & $8.59^{b}$ & $8.51^{\mathrm{b}}$ & 8.55 & $22.44^{\mathrm{b}}$ & $22.43^{b c}$ & 22.44 & $403^{c}$ & $386^{b}$ & 395 \\
\hline $\mathrm{Zn}_{4}: 12$ & $7.48^{b}$ & $7.15^{\mathrm{b}}$ & 7.32 & $2.34^{\mathrm{a}}$ & $1.81^{\mathrm{a}}$ & 2.08 & $8.62^{b}$ & $8.55^{\mathrm{ab}}$ & 8.59 & $22.58^{\mathrm{ab}}$ & $22.54^{b}$ & 22.56 & $423^{b}$ & $403^{a}$ & 413 \\
\hline$Z_{5}: 14$ & $7.60^{\mathrm{a}}$ & $7.25^{\mathrm{a}}$ & 7.43 & $2.41^{a}$ & $1.83^{\mathrm{a}}$ & 2.12 & $8.79^{a}$ & $8.60^{\mathrm{a}}$ & 8.70 & $22.76^{\mathrm{a}}$ & $22.70^{\mathrm{a}}$ & 22.73 & $442^{\mathrm{a}}$ & $411^{\mathrm{a}}$ & 427 \\
\hline LSD 5\% & 0.06 & 0.07 & & 0.08 & 0.03 & & 0.10 & 0.09 & & 0.18 & 0.14 & & 0.05 & 0.10 & 13.75 \\
\hline$S x^{-}$ & 0.031 & 0.036 & & 0.038 & 0.013 & & 0.049 & 0.047 & & 0.091 & 0.069 & & 0.028 & 0.050 & \\
\hline Interaction(BXC) & $* *$ & $* *$ & & $* *$ & $* *$ & & $* *$ & $* *$ & & $* *$ & ** & & ** & ** & \\
\hline
\end{tabular}

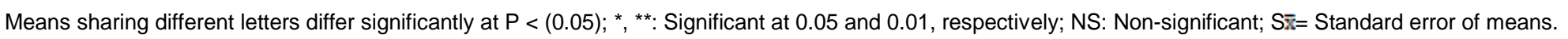

significant correlation of yield with all the morphological characteristics.

\section{DISCUSSION}

From the kernel quality point of view, increasing levels of irrigation and $\mathrm{Zn}$ application rates produced the maximum length of kernel in super Basmati. The $I_{5} Z n_{5}$ treatment combination increased the plant height and positively influenced most yield attributes in super Basmati rice and finally resulted in increased rice yield. It is known that $\mathrm{Zn}$ concentration and uptake by rice also increased with the level of $\mathrm{Zn}$ application. Such a response of rice on such soils was expected as reported by
Takkar et al. (1989). Ponnamperuma (1972) also observed that lowland soils are generally prone to $\mathrm{Zn}$ deficiency due to reduced availability of $\mathrm{Zn}$ in the soil and suppression of its uptake by high levels of iron and manganese. Lack of proper water management is probably the most wide spread constraint to higher rice yield and quality (Sharma and Sarkar, 1994). The higher percentage 
Table 5. Correlation coefficient between grain yield and morphological characteristics of aromatic rice.

\begin{tabular}{lccc}
\hline Character & Sheikhupura & Sargodha & Pooled \\
\hline Grain yield vs. spikelet sterility & $0.973^{* *}$ & $0.418^{\mathrm{NS}}$ & $0.898^{* *}$ \\
Grain yield vs. abortive kernels & $0.732^{* *}$ & $0.663^{*}$ & $0.859^{* *}$ \\
Grain yield vs. opaque kernels & $0.971^{* *}$ & $0.342^{\mathrm{NS}}$ & $0.871^{* *}$ \\
Grain yield vs. normal kernels & $0.855^{\star *}$ & $0.815^{\star *}$ & $0.834^{* *}$ \\
Grain yield vs. kernel length & $-0.373^{\mathrm{NS}}$ & $0.812^{\star *}$ & $0.913^{* *}$ \\
Grain yield vs. kernel width & $0.929^{* *}$ & $0.821^{* *}$ & $0.923^{* *}$ \\
Grain yield vs. water absorption ratio & $0.708^{* *}$ & $0.646^{*}$ & $0.713^{* *}$ \\
Grain yield vs. kernel protein contents & $0.775^{* *}$ & $0.623^{*}$ & $0.686^{*}$ \\
Grain yield vs. kernel amylose contents & $0.833^{* *}$ & $0.039^{N S}$ & $0.766^{* *}$ \\
\hline
\end{tabular}

*, ** Significant at 5 and $1 \%$ level; ${ }^{\text {ns }}$ non-significant.

of normal kernels with the increasing rate of irrigation and $\mathrm{Zn}$ levels may be due to adequate supply of irrigation and $\mathrm{Zn}$ that enhanced the availability of other nutrients like $\mathrm{N}$, $\mathrm{P}$ and $\mathrm{K}$, and partly due to low competition among plants. Thus kernels under these conditions developed in the absence of any water stress or nutritional stress (Ahmad et al., 2009; Khan et al., 2009; Shivay et al., 2010). Iqbal (2004) found that yield of rice increased 50 to $60 \%$ in response to the application of $\mathrm{N}, \mathrm{P}$ interaction with water. Results reported also showed that under normal conditions the kernel length and width increased over lower rates of irrigation and $\mathrm{Zn}$ application by 8 to 10 times. Shivay et al. (2005) concluded that $\mathrm{Zn}$ fertilization had no deleterious effects on the quality of Basmati rice; it even increased hulling percentage and producing longer and better grains.

\section{Conclusion}

Super basmati fine rice kernel quality and morphological traits were significantly impacted by irrigation and zinc application. Increasing rates of irrigation and zinc applications showed significant effects on spikelet sterility, percentage of abortive and opaque kernels at both the sites. The percentage of normal kernels was also significantly increased. Kernel dimensions such as length and width were also significantly affected by the increasing rates of treatments. At both sites, increasing rates of $\mathrm{I}$ and $\mathrm{Zn}$ significantly increased kernel protein and amylose contents compared to control or lower rates of $I$ and $Z n$ treatments.

\section{REFERENCES}

Ahmad A, Hussain A, lqbal S, Husnain Z (2005). Growth, radiation use efficiency and paddy yield of fine rice (Super basmati) as affected by sowing date and split nitrogen application. Proceedings of the International Seminar on Rice Crop. Oct. 2-3, 2005.RRI, Lahore Pak. pp. 315-321.

Ahmad S, Ashfaq A, Muhammad Z, Hakoomat A, Tasneem K, Anjum MA, Khan M, Abid H, Gerrit H (2009). Resources use efficiency of field grown transplanted rice (Oryza sativa L.) under irrigated semiarid environment. J. Food Agric. Envt. 7(2):487-492.

Crusciol CAC, Arf O, Soratto RP, Machado JR (2003). Milling quality and nutrient content of grains of upland rice as affected by water and mineral fertilizer levels. Acta Sci. Agron. 25(2):409-415.

Fageria NK, Santos AB, Cutrim VA (2008). Dry matter and yield of lowland rice genotypes as influence by nitrogen fertilization. J. Plant Nutr. 31(4):788-795.

GOP (2009). Economic Survey of Pakistan 2008-2009, Finance Division, Economic Advisory Winglslamabad Pak. P. 20.

Homer DC, Pratt PF (1961). Methods of analysis of soils, plants and waters. Univ. of California, Div. Agri. Sci., USA. pp. 150-196.

Hussain M, Ali MA, Randhawa MA, Nawaz M (2005). Determining the effects of mixing of ZnSO4 with different fertilizers on the growth and yield of rice.Proceedings of the International Seminar on Rice Crop. Oct. 2-3, 2005. RRI Lahore Pak. pp. 126-129.

lqbal MT (2004).Yield and biomass in rice interaction of nitrogen, phosphorous and water applications. Pak. J. Bio. Sci. 7(12):21152120.

Jacobs MB (1958). The chemical analysis of food and food products. Roberts A.V. Pub. Co. NY USA. pp. 32-35.

Juliano BO (1971). A simplized assay for milled rice amylase.Cereal. Sci. Today. 16(10):334-340.

Juliano BO, Onate LU, Deb-Mundo AM (1965). Relations of starch composition, protein content and gelatinization temperature to the cooking and eating quality of milled rice. Food Technol.19(12):10061011.

Khan R, Gurmani AR, Khan MS,Gurmani AH (2009). Residual, direct and cumulative effect of zinc application on wheat and rice yield under rice-wheat system. Soil. Envt. 28(1):24-28.

Mirzavand $J$ (2007).Effects of soil application of zinc sulfate and immersing of seedling roots in zinc oxide suspension on yield and chemical composition of rice (CV Ghasrodashti). Ir. J. Soil. Water Sci. 21(1):23-31, 3.

Moodie CD, Smith NW, Mc-Greery RA (1959). Manual for Soil Fertility Development in Corn (Zea mays L.) and subsequent grain yield. Crop Sci. 11:368-372.

Nagato K, Chaudhry FM (1969).A comparative study of ripening process and kernel development in Japonica and Indica rice. Proc. Crop Sci. Soc. Japan. 38(3):425-433.

Ponnamperuma FN (1972). Chemistryof submerged soils. Adv.in Agron. 24:29-95

Sharma BR, Sarkar TK (1994). Efficient water management: a key to sustainable food production. Ind. Farming. 44:7-12.

Sharma P, Dhillon KS, Dhillon SK (2008). Impact of distillery effluent application along with inorganic fertilizers on dry matter yield and mineral composition of rice.Acta. Agron. Hung. 56(2):187-201.

Shivay YS, Prasad R, Rahal A(2010).Genotypic variation for productivity, zinc utilization efficiencies and kernel quality in aromatic rice under low available zinc conditions. J. Plant Nutr. 33(12):18351848.

Shivay YS, Kumar D, Prasad R (2008). Effect of zinc-enriched urea on 
productivity, zinc uptake and efficiency of an aromatic rice-wheat cropping system.Nut. Cyc.in Agroeco. 81(3):229-243.

Shivay YS, Kumar D, Prasad R (2005). Effects of zinc fertilization on physical grain quality of basmati rice.Int. Rice Res. Newsletter. 32(1):41-42.

Steel RGD, Torrie JH, Dickey DA (1997). Principles and Procedures of Statistics. Biometrical Approach. McGraw Hill Book Co. NY USA. pp. 400-428.

Takkar PN, Chhibba IM, Mehta SK (1989). Twenty years of coordinated research on micronutrients in soils and plants. Bulletin I. Bhopal, India: Indian Institute of Soil Science.

Xie G, Yu J, Wang H, Bouman BAM (2008) Progress and yield bottleneck of aerobic rice in the north china plain: A case study of varieties Handao 297 and Handao 502. Agric. Sci. China. 7(6):641646. 